\title{
Assessment of Some Anionic Parameters and Organic Components, as Pollution Indicators in Drinking Water Sources in Rural Areas of Abuja "F.C.T", Nigeria
}

\author{
Odoh Raphael*, Udegbunam Ifeoma Sandra, Yebpella Garbunga Gary \\ Department of Chemical Sciences, Federal University Wukari, Taraba State, Nigeria
}

*Corresponding Author: Odoh Raphael, Department of Chemical Sciences, Federal University Wukari, Taraba State, Nigeria

\begin{abstract}
Analyses of water sample from different drinking water sources in rural areas of Bawari, Kuje, Gwagwalada, Kwali area of Abuja FCT, was carried out to ascertain the magnitude ofphysico chemicals, anions and organic pollution of drinking water sources. All the drinking water sources in the areas were examined. The parameters determined included; temperature, $\mathrm{pH}$, Electrical conductivity (EC), total dissolved solids (TDS), turbidity, Total Hardness, Nitrate, Nitrite, Chloride, sulphate, phosphate, trihalomethanes (Chloroform $\left(\mathrm{CHCl}_{3}\right)$, Dibromochloromethane $\left(\mathrm{CHBr}_{2} \mathrm{Cl}\right)$, bromodichloromethane $(\mathrm{CHBr}$ $\mathrm{Cl}_{2}$ ) and bromoform $\left(\mathrm{CHBr}_{3}\right)$. using convectional equipment and standard laboratory procedures. Some of these parameters indicated traceable pollution but were below the World Health Organization (WHO) Standard for drinking water quality limits for consumption. Statistical analyses indicated insignificant differences among all the parameters tested for in the samples at 95\% level. The results found that physical parameters tested such as turbidity, pH, TDS, conductivity, and colour did not indicate any reason for concern. All the physico - chemical parameters remained almost constant with little variations over time. Although there are some variation, but the variations over time for these parameters studied were within recommended guidelines. These variations were too insignificant to be of major concern to the people drinking and used such water sources. This therefore made the water from the sources fit for human consumption but water treatment still required because of the other parameters that may be of health threat that were not considered in this study.
\end{abstract}

Keywords: Anions, Assessment, Drinking Water Sources, Indicators, Organic Components, Pollution, Rural Areas.

\section{INTRODUCTION}

Good drinking water sources has always been a major issue in many rural areas in Nigeria, many of the rural populace do not have access to adequate water and therefore, depend on other alternatives like wells, borehole, stream and river, rain water for drinking and domestic use. The assessment of these water quality statuses is important for socio-economic development of any area of the world. The determination of drinking-water quality for human consumption is important for the well-being of the ever increasing population. Good quality water will ensure the sustainability of socio-economic development, rather than channelling the resources towards combating outbreaks of water borne diseases due to consumption of contaminated water. Drinking-water quality depends, to some extent, on its chemical composition [9] which may be modified by natural and anthropogenic sources. As drinking-water sources have a huge potential to ensure future demand for water, it is important that human activities on the surface do not negatively affect these precious resource [10]. It was emphasized the importance of these water sources globally as a source for human consumption and changes in quality with subsequent contamination can, undoubtedly, affect human health. The World Health Organization has estimated that $80 \%$ of all sickness and diseases in the world are attributable to unhygienic water [9]. Water borne diseases are among the leading causes of death in many developing countries today. In addition to the alarming mortality rates, it is estimated that people in developing countries lose $10 \%$ of their productive time because of disease related to poor and contaminated water [12]

Organic chemicals have been widely detected in water sources, most commonly found organic chemicals in drinking water systems are tetrachloroethylene or perchloroethylene, trichloroethylene, 
1,1,1-trichloroethane and vinylidene chloride or 1,1-dichloroethylene. There are concerns that some of these volatile organic chemicals cause cancer, but data on this and reproductive effects are mainly from animal studies, data from human studies are limited. The most common synthetic organic chemicals used are by-products produced when chlorine is being used to disinfect the water. When chlorine reacts with natural organic material in the water the trihalomethanes (THMs) are produced. The THMs include chemicals such as chloroform (dichloromethane), bromoform, bromodichloromethane and dichlorodibromomethane. Chloramines on the other hand are used as an alternative to disinfect the water and produces fewer THMs. Chloramines are less effective than chlorine. Kidney dialysis facilities remove chloramines because they can damage red blood cells [7]. Historical disease outbreaks in drinking water utilizing any water source is still of concern [9]. Untreated water sources are subjected to contamination from animal populations and excessive runoffs during severe storms, resulting in water pollution. Ground water is considered to be safe and free of disease causing microbes. The most dangerous form of groundwater water pollution by these microbes is human enteric viruses, ulcer causing bacteria, and protozoa (cryptosporidium) [9]. Groundwater is a commonly used term to refer to water that has percolated from ground surface through the soil pores. They are vital source of water supply, especially in rural areas where dry summers or extended droughts cause stream flow to stop. Each groundwater system in an area is known to have a unique chemistry, which is acquired as a result of chemical alteration of the meteoric water recharging the system [10].

During rainfall, water tends to dissolve particulate matters, atmospheric gases such as $\mathrm{CO}_{2}, \mathrm{CO}, \mathrm{N}_{2}$, $\mathrm{NO}_{2}, \mathrm{SO}_{2}$ and other green house gases that are present in the atmosphere. Dissolution of these substances in rainwater compromises the natural purity of rainwater. On reaching the earth's surface, some of these solute components are associated with the acid rain phenomenon [3]. Surface water on the other hand is the most contaminated water body as it is interfaced between the earth crust and the atmosphere. The earth crust is composed of mainly silicate minerals that can be washed off or weathered by running surface water, and this has the effect of likely increasing the turbidity of surface water. However, besides natural factors, anthropogenic factors particularly those that tend to introduce harmful substances to the soil are also of significance in the evolution of water quality [9]. Effluent discharges from industry, fertilizers/manures application on farmland are some examples. Some of these substances could undergo secondary changes, as they are washed along the soil strata [8]. This is more likely to take place with water containing dissolved ionic solutes that could replace metallic ions from the silicate minerals [1]. Some drinking water is grossly polluted at its source such as rivers, streams, and underground aquifers. A considerable number of studies have attempted to correlate the incidence of water-borne and water-associated diseases with water supply availability and the quality of the water. The overall findings confirm that a better water supply and of good quality leads to better health. Drinking-water or water quality is mainly controlled by the range and type of human influence as well as geochemical, physical and biological processes occurring in the area [11]. It therefore becomes imperative to regularly monitor the quality of the drinking-water consumed in some rural areas. A lot of works had been done on water but most of the works were on heavy metals and most of them were carried out in cities and urban areas so, this study therefore is to investigate some anionic and organic as a pollution indicator of drinking water source in some of the rural areas of Abuja "FCT" Nigeria.

\section{MATERials AND MethodS}

\subsection{Study Area}

Abuja is located between latitude $7^{1} 20^{0}$ north of the equator and longitude $6^{1} 45$ and $7^{1} 39^{0}$ east of greenwich. The capital territory occupies a land area of 8,000 square kilometres. It is bounded on the north by Kaduna state, on the west by Niger state. On the east and south by Nassarawa state and on the south-west by Kogi state. Federal Capital Territory consist of six area councils namely Municipal, Bawari,Kuje, Gwagwalada, Kwali and Abuja.

Abuja has a tropical sub-humid climate, with two distinct seasons, namely a wet and dry season. The wet season lasts for seven months starts from April and ends in October. Its major elements have regimes that are transitional from those of the southern and northern parts of the country. Thus, 
relative humidity is not as high as in the northern parts and temperatures are not as high as in the far north either. The annual rainfall total ranges from $1,200 \mathrm{~mm}$ to $1,500 \mathrm{~mm}$. Temperatures are generally very high during the day, particularly in the months of March and April. Gwagwalada, one of the area councils, for example, records average maximum and minimum daily temperatures of $35^{\circ} \mathrm{C}$ and $21^{\circ} \mathrm{C}$ in summer and $37^{\circ} \mathrm{C}$ and $16^{\circ} \mathrm{C}$ in winter, respectively.

\subsection{Sample Collection}

Water samples were collected from different communities of area councils of Abuja, namely Bawari, Kuje, Gwagwalada, Kwali from different drinking water source respectively: rivers/streams, boreholes, wells, and rainwater storage, using plastic containers. The choice of area for sample collection was guided by availability of such drinking water sources.

The water sample containers used were washed and rinsed with 5\% nitric acid and was again later rinsed with distilled water after which they were dried before use for sample collection. About threefive separate samples were collected at regularly intervals from each of the water sources rivers/streams, boreholes, wells, and rainwater harvest. Water bottles were capped tightly after sample collection. The samples were then kept refrigerated before they were analyzed. The samples were labelled as coded. Composite samples were obtained from all sets of source samples (surface and underground water). The obtained composite of each sample was again split into three equal parts for the laboratory analysis. Each set of sample was preserved according to specific needs of the intending analysis [9].

Parameters investigated include $\mathrm{pH}$, temperature, electrical conductivity, turbidity and total dissolved solidand were estimated using standard methods. Ion chromatography (Metrohm 761 Compact ICsystem A) was the analysis method used to determine the common anions such as fluoride, chloride, nitrite, bromide, nitrate, sulphate and phosphate. Most organic determinants (measured in $\mu \mathrm{g} / \mathrm{l}$ ), which may have direct health impact if such water is consumed, were determined using various accredited laboratory methods. Organic chemical contaminants were determined with Gas Chromatography with electron capture detection (GC-ECD) and headspace auto sampler was used on all water samples to determine trihalomethanes (Chloroform $\left(\mathrm{CHCl}_{3}\right)$, Dibromochloromethane $\left(\mathrm{CHBr}_{2} \mathrm{Cl}\right)$, bromodichloromethane $\left(\mathrm{CHBrCl}_{2}\right)$ and bromoform $\left(\mathrm{CHBr}_{3}\right)$. Water samples were prepared with the internal standard (i.e. 1, 2 dibromoethane), isothermically heated and injected into gas chromatograph. Analyses were performed using an electron capture detector and a computerized data analysis program. The quality control standard was analysed after every tenth sample. The blank chromatogram was checked to ensure that the system was free from contamination. The verification standard was run after every 10th sample during the analysis.

\section{RESULTS AND DISCUSSION}

The result of parameters selected in this study to assess the impact of such parameters on quality of the drinking water sources in the studied areas are presented in figure 1 to figure 5 and summary of the result in Table 1. The results were similar; the similarity of the result is an indication that the source of pollutions and contaminations were similar in all drinking water sources in the study areas. Because of the similarity in pollutions and contaminations pattern in the sources of the drinking water, focusing on the comparison between the water sources will be futile; instead, the general profile of each parameter will be discussed focusing attention to any anomaly. For instance, turbidity is used to measure the clarity of the water. The average turbidity readings of the samples were above the WHO standard. The water samples having average turbidity values of $5.75 \pm 1.140$ and ranged from 2.30 to 7.50 NTU. Presence of suspended particles and other materials are usually responsible for high turbidity values. Similar high turbidity values were also reported in similar research [11] indicating that the wells may be unlined hence the high values. Soil particles may have found their way into the water sources either through runoff or from the unstable side walls thereby increasing turbidity of the water sources. A similar observation was made by [6] and the reasons adduced for the observation was as mentioned above. The [8] recommended a value of 5.00 NTU as the maximum above which disinfection is inevitable. The observed average turbidity value in samples were slightly higher than the recommended value but all the values were however lower than the ones reported in the similar studies [13]. 


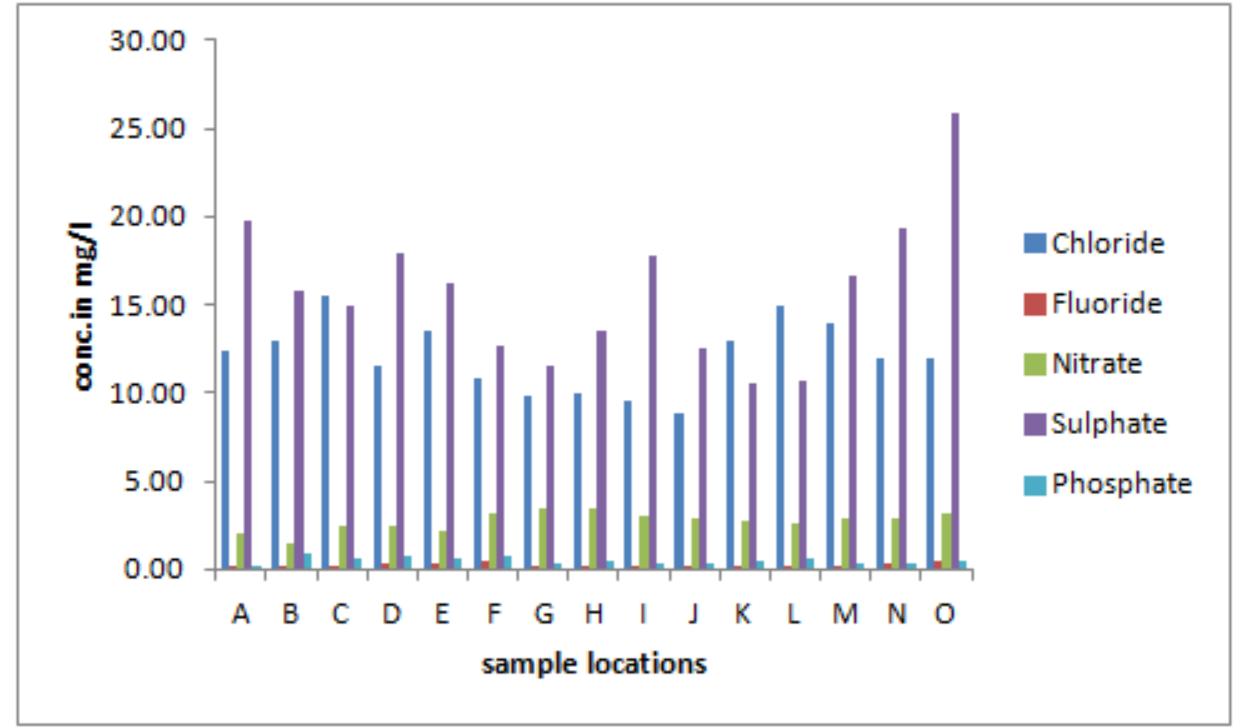

Figure1. Anion contents of drinking water samples

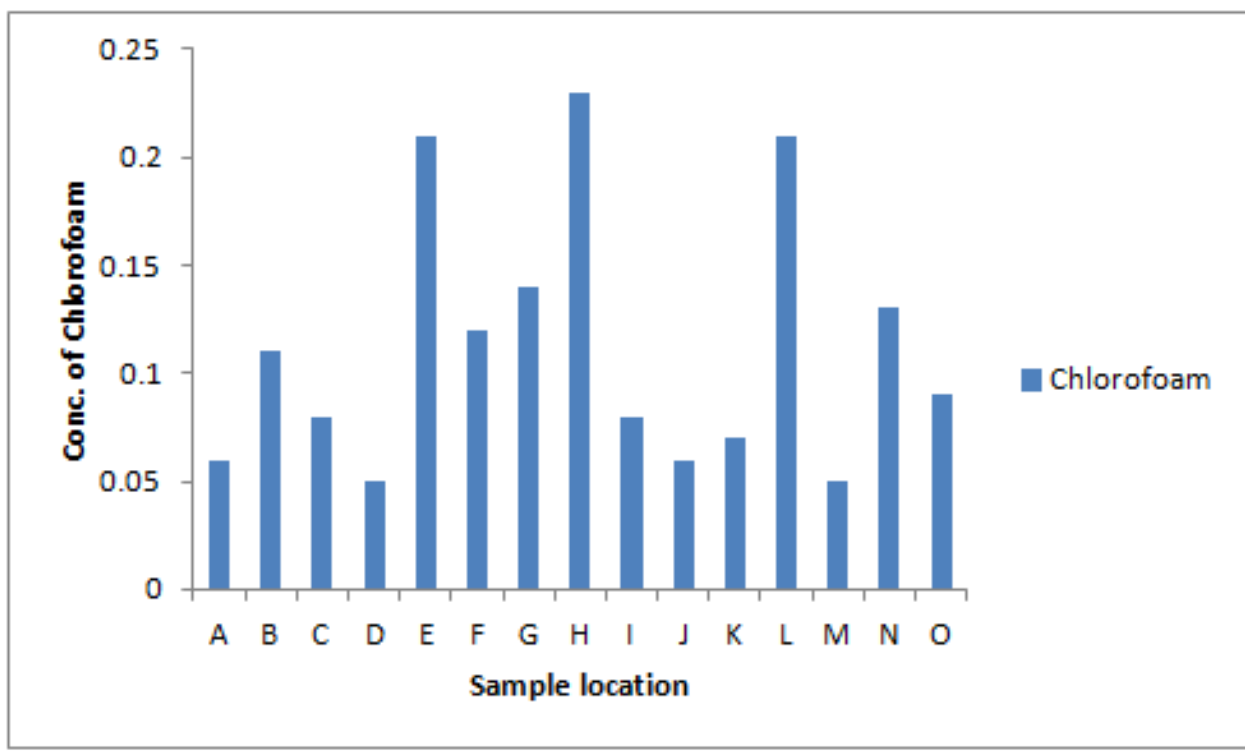

Figure2. Chloroform contents of drinking water samples

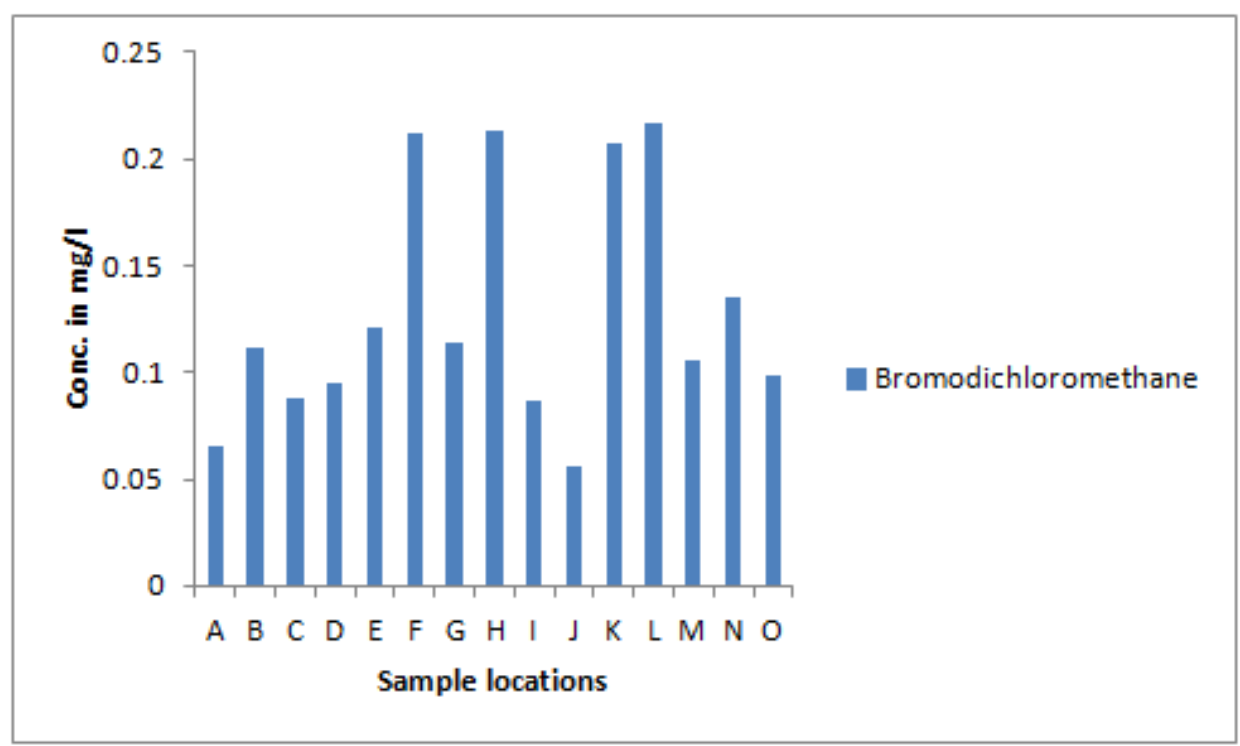

Figure3. Bromodichloromethane contents of drinking water samples 


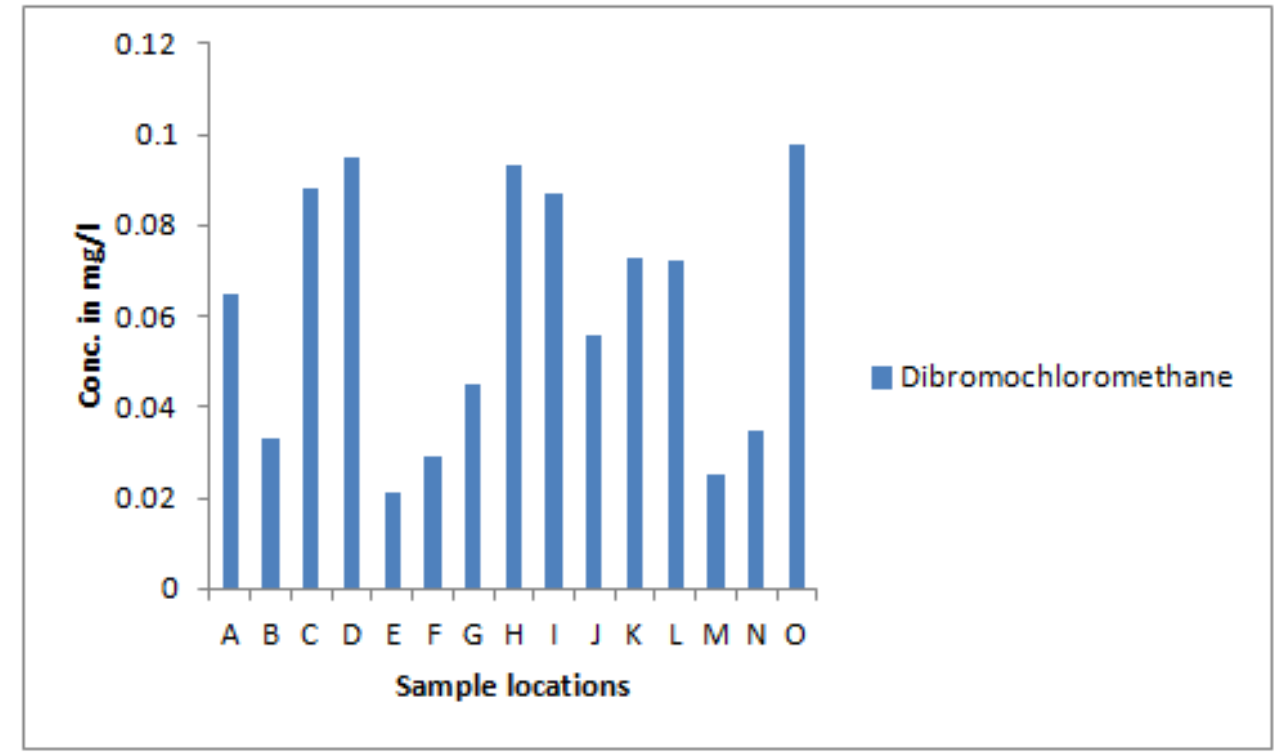

Figure4. Dibromochloromethane contents of drinking water samples

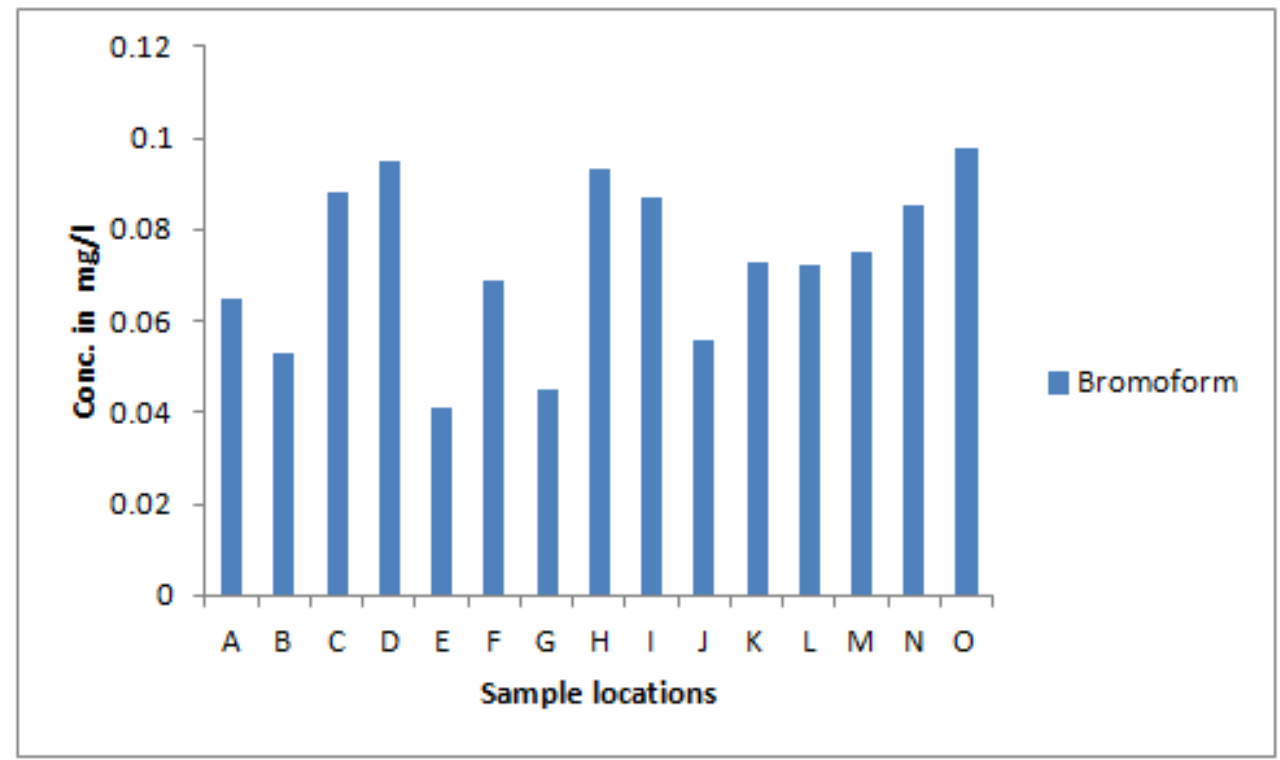

Figure5. Bromoform contents of drinking water samples

Table1. Summary of Physico-Chemical Parameters of Drinking water sources in the Study Areas

\begin{tabular}{|c|c|c|c|c|c|}
\hline Parameter & Range & Mean \pm S.D & Range & Mean \pm S.D & W.H.O \\
\hline Temp. & $27.90-29.00$ & $28.40 \pm 0.35$ & $28.90-29.00$ & $28.49 \pm 0.35$ & \\
\hline PH & $6.10-6.90$ & $6.62 \pm 0.25$ & $6.20-8.80$ & $7.39 \pm 0.82$ & $6.50-9.20$ \\
\hline E.C & $110.00-215.00$ & $171.27 \pm 33.23$ & $120.00-230.00$ & $180.00 \pm 36.01$ & 500 \\
\hline TDS & $150.00-260.00$ & $211.47 \pm 26.02$ & $200.00-350.00$ & $249.87 \pm 44.15$ & 500 \\
\hline Turbidity & $2.30-9.00$ & $6.73 \pm 1.74$ & $2.30-7.50$ & $5.75 \pm 1.14$ & - \\
\hline $\mathrm{Cl}^{-}$ & $8.90-15.50$ & $12.05 \pm 2.00$ & $7.50-10.80$ & $9.07 \pm 1.09$ & $0-200.00$ \\
\hline $\mathrm{NO}_{2}$ & $0.40-0.81$ & $0.59 \pm 0.14$ & $0.20-0.51$ & $0.32 \pm 0.09$ & - \\
\hline $\mathrm{NO}_{3}$ & $1.50-3.50$ & $2.72 \pm 0.52$ & $1.10-2.90$ & $2.15 \pm 0.60$ & $40.00-70.00$ \\
\hline $\mathrm{SO}_{4}$ & $10.50-25.90$ & $15.72 \pm 4.14$ & $10.50-15.80$ & $12.85 \pm 1.76$ & $0-250.00$ \\
\hline $\mathrm{PO}_{4}$ & $0.20-0.90$ & $0.15 \pm 0.20$ & $0.20-0.50$ & $0.35 \pm 0.11$ & $0-5.00$ \\
\hline $\mathrm{Hardness}$ & $29.00-50.50$ & $41.30 \pm 7.68$ & $39.00-60.00$ & $47.10 \pm 6.36$ & $0-1.00$ \\
\hline
\end{tabular}

Temperature: The temperature of the drinking water samples are similar across the drinking water sources, all the water sample having a temperature range of $28.90-29.00^{\circ} \mathrm{C}$ with average value of $28.49 \pm 0.35{ }^{\circ} \mathrm{C}$. High water temperature enhances the growth of micro organisms and this may increase taste, odour and corrosion problems. There is no guideline value recommended for drinking 
water temperature since its control is usually impracticable (WHO, 2008). The high temperature signified presence of active micro organisms which resulted in the temperature increase.

Total dissolved solids (TDS) and electrical conductivity (EC) are the two main determinants used to determine salt content. TDS constitutes all the dissolved solids in the water. It is usually comprised of inorganic minerals (salts), small amounts of organic material and soluble minerals (Fe and $\mathrm{Mn}$ ). The inorganic minerals (salts) are commonly found in nature and are deposited by the weathering of the sedimentary rocks and erosion of the earth's surface. TDS gives an indication of whether or not all suspended solids were contained in the drinking water sources. The TDS ranged from $200.00-$ 350.00 for drinking water sources studied. High levels of TDS may also cause an objectionable taste, odour and colour to the water. It is evident from results (Table1 and 2) that there was significant TDS variation between drinking water sources studied. Hence the TDS concentration varied between the drinking water sources since the drinking water came from different source. TDS values were within drinking water standard of $1000 \mathrm{mg} / \mathrm{L}$ with average TDS values of $249.87 \pm 44.15 \mathrm{mg} / \mathrm{L}$ for drinking water sources studied. The TDS for all drinking water sources tested was within the recommended limits and won't have negative effects.

$\mathrm{pH}$ is one of the most important operational water quality determinants. The closer $\mathrm{pH}$ gets to 1 , the more acidic the water becomes. According to WHO drinking water standard $\mathrm{pH}$ limits for drinking water are supposed to be between $\geq 5.0$ to $\leq 9.5$ ( $\mathrm{pH}$ units). The $\mathrm{pH}$ values ranged from 6.20 to 8.80 for drinking water sources. No significant variations were noticed during the period of study. International standards for drinking water suggest that $\mathrm{pH}$ less than 6.5 or greater than 9.2 would impair the portability of the water. All the drinking water sources tested were within the specified standard between 5.0 and 9.5 with average values of $7.39 \pm 0.82$ for drinking water sources studied. The weakly acidic nature of drinking water sources may be traceable to some dissolved matter in the water. For instance, rainwater being the major source of groundwater recharge, dissolves greenhouse gases during rainfall, it is the dissolution of these gases that is responsible for increasing rainwater acidity $[1,9]$. Also, the $\mathrm{pH}$ of rainwater tends to be higher than that of groundwater, and this is as a result of differences in the chemical dynamics of the two water source types. One of the major reasons why groundwater is likely to become more acidic is that more carbon dioxide from organic matters present in the soil could further dissolve in percolating water during percolation, before they reach an aquifer system.

The presence of chloride in natural waters is due to the effluents from chemical industries, wastewater treatment plants, road salting and agricultural runoff. It is also present in water, rocks, soil and many foods. Chloride may also contribute towards total dissolved solids in drinking water. High concentrations of chloride in drinking water may result in a salty taste giving drinking water the same salty taste. Chloride is an essential element for humans (WHO, 2003). All drinking water source tested remained constant during the period of study. Average values of $(12.05 \pm 2.00 \mathrm{mg} / \mathrm{L}$ for chloride concentrations complied with WHO limit drinking water standard of $<200 \mathrm{mg} / \mathrm{L}$. There is no evidence that intake of chloride in large quantity in drinking water can harm humans.

Fluoride $\left(\mathrm{F}^{-}\right)$, the most important source of fluoride is drinking water. High fluoride dose exposure for extended periods produces skeletal fluorosis (brittle bones) and discoloured teeth (Ncube and Schutte, 2005). Concentrations lower than recommended levels for drinking water to provide protection may result in dental caries, especially in children (Ncube and Schutte, 2005). However, fluoride may contain varying concentrations of naturally occurring fluoride depending on the water source. No particular trend was noticed over time as fluoride concentration fluctuated for all drinking water sources investigated with the highest fluoride concentrations observed in location F. There were variations during the period of study as fluoride concentrations fluctuated from all the drinking water sources tested. Results showed site F to have a fluoride maximum concentration of $0.450 \mathrm{mg} / \mathrm{l}$, for site $\mathrm{D}$ and $\mathrm{O}, 0.420 \mathrm{mg} / \mathrm{l}$ and $0.330 \mathrm{mg} / \mathrm{l}$ for site E. All the drinking water sources tested complied with the WHO and EC drinking water standard.

Although low levels of nitrates may occur naturally in water, sometimes higher levels, which are potentially dangerous to human, are found. Sources of nitrates and nitrogen may include runoff or seepage from fertilized agricultural lands; municipal and industrial waste water, private sewage disposal systems, urban drainage and decaying plant debris. Infants are especially susceptible because 
their stomach juices are less acidic and therefore are conducive to the growth of nitrate-reducing bacteria. Adults can consume large quantities of nitrates in drinking water or food with no known ill effects; their stomachs produce strong acids that do not promote the growth of bacteria that convert nitrate to nitrite. Therefore, drinking water that is high in nitrates should not be used for preparing infant formula or in any other way that could result in consumption by a baby. Observations from all drinking water sources have a similar trend of nitrate concentration fluctuation, nitrate concentration increased shown irregularly trend during the period of study and nitrate concentration almost remained constant throughout the study. All drinking water sources tested complied with WHO limit of $15 \mathrm{mg} / \mathrm{L}$ with average concentrations of $2.720 \pm 0.520 \mathrm{mg} / \mathrm{L}$.

Total Hardness: The values for the drinking water samples are not consistent. Water samples have a total hardness ranged from $29.00-50.50 \mathrm{mg} / \mathrm{L}$. All the water samples are within the WHO (2008) 100$300 \mathrm{mg} / \mathrm{L}$ guideline limit for drinking water. According to WHO ecological and analytical epidemiological studies, there is a significant inverse relationship between hardness and drinking water. However the degree of hardness in the water may affect its acceptability to the consumer in terms of scale deposition (WHO, 2004). All the drinking water sources tested has shown insignificant increase in the parameters studied and their concentrations were within the required drinking water standard.

Sulphate occurs naturally in numerous minerals and is used commercially, principally in the chemical industry. They are discharged into water in industrial wastes and through atmospheric deposition; however, the highest levels usually occur in drinking water source are from natural sources. In general, the average daily intake of sulphate from drinking-water, air and food is approximately 500 $\mathrm{mg}$, food being the major source. No health-based guideline is proposed for sulphate. However, because of the gastrointestinal effects resulting from ingestion of drinking-water containing high sulphate levels (WHO,2004). The results from this research in Table 1 and 2 showed insignificant increase in sulphate concentrations during the period of study for drinking water source. All results attained were compliant with WHO drinking water standard of $250 \mathrm{mg} / \mathrm{L}$ with average values of $15.725 \pm 4.135 \mathrm{mg} / \mathrm{L}$.

Phosphate levels in all the water samples were in the range of $0.20-0.90 \mathrm{mg} / \mathrm{L}$, with an average of $0.15 \pm 0.20 \mathrm{mg} / \mathrm{L}$. The WHO guideline value for phosphate in drinking water is $5 \mathrm{mg} / \mathrm{L}$. Thus, all the samples studied were within the limit. The water can be said to be of good quality in terms of phosphate content. The low level of phosphate may be due to low phosphate containing rocks system or absence of such rock system around the study areas [28]. It could also be due to minimal use of phosphate containing fertilizers around these areas.

Organic determinants results: Trihalomethanes consist mainly of Chloroform, Bromodichloromethane, Dibromochloromethane and bromoform and they are a family of chemicals created when chlorine is used to disinfect the water (chlorine reacts with organic matter in the water to form THMs and other by-products). The amount of each THM formed depends on the temperature, $\mathrm{pH}$, chlorine and bromide ion concentrations. Studies conducted revealed that people and animals exposed to THMs in their drinking water have the risk of suffering from the colon, kidney or liver cancer and a higher potential to suffer from reproductive disorders such as spontaneous abortion and birth defects [5]. There was no variation during the period of study from all drinking water source tested. This is typical as most drinking water derived from similar sources (e.g. underground, springs) have insufficient traces of chlorine or no chlorine at all in order to react with organic material in the water. Chloroform is commonly found in drinking water (sourced from the tap); it is of public health concern because consumption in excessive amounts can be carcinogenic, shows that chloroform was below the WHO limit of $<0.200 \mathrm{mg} / \mathrm{l}$. There was no variation during the period of study from any drinking water sources tested (i.e. well, borehole, stream/river and rain water storage). Drinking water sources were within the WHO guideline value of $0.200 \mathrm{mg} / \mathrm{l}$. Bromodichloromethane was below the WHO limit of $<0.100 \mathrm{mg} / \mathrm{l}$ (Figure 42). Dibromochloromethane and bromoform indicated no significant variation during the period of study as they were within guideline value of $0.1 \mathrm{mg} / \mathrm{l}$. Gas Chromatograph-ECD used to test for various trihalomethanes, have different detection limits for various trihalomethanes tested. 


\section{CONCLUSiON}

The analysis of some anions and organic contents of the drinking water sources was carried out in some rural areas of Abuja "FTC". Apart from the average turbidity readings of the samples which were above the WHO standard. The result of the analysis revealed that all the other parameters determined in the drinking water sources from the study areas are within acceptable limit. Although all the parameters study were present in the drinking water sources analyzed but the present concentrations may not pose any serious health hazard because all parameters examined in the drinking water sources have values that are below or within the maximum permissible limit of WHO, FAO and EC Standards, hence the present result may not pose any serious health hazard, but attention should be given to turbidity. In order to protect public health, all the drinking water sources need to be monitored and protected this is to ensure that the anions and organic particles are not present in excess concentration.

\section{REFERENCES}

[1] OkoroE.I., EgbokaB.C.E., AnikeO.L., Onwuemesi A.G. (2009): Integrated water resources management of the Idemili River and Odo River drainage basins, Nigeria. Improving Integrated Surface and Groundwater Resources Management in a Vulnerable and Changing World (proc. of JS .3 at the Joint IAHS \& IAH Convention, Hyderabad, India, IAHS Publ. pp.117-122.

[2] Ogedengbe K.and Akinbile C. O. (2004): Impact of Industrial Pollutants on Quality of Ground and Surface waters at Oluyole Industrial Estate, Ibadan, Nigeria, Nigerian J. of Technol Dev, 4 (2): 139-144

[3] Sarukkalige P.R. (2009): Impact of land use on groundwater quality in Western Australia. Improving Integrated Surface and Groundwater Resources Management in a Vulnerable and Changing World (proc. of JS .3 at the Joint IAHS \& IAH Convention, Hyderabad, India, IAHS Publ. pp. 136-142.

[4] ShyamalaR., ShantiM., and Lalitha P. (2008): Physicochemical Analysis of Borewell Water Samples of Telungupalayam Area in Coimbatore District, Tamilnadu, India, E-J. of Chem, 5 (4): 924-929.

[5] Ramakrishnaiah C.R., Sadashivaiah C, RangannaG. (2009): Assessment of Water Quality Index for Groundwater in Tumkur Taluk, Karnataka State, India. E-Journal of Chemistry. 6(2): 523-530.

[6] Raphael Odoh, and Godwill Jidauna (2013): The Spatial Effect of Rusty Roof on Water Quality in Otukpo Local Government Area of Benue State, Nigeria. International Journal of Marine, Atmospheric \& Earth Sciences, 1(1): 27-37.

[7] Odoh R. and DaudaM. S. (2013): Survey of Heavy Metal Contamination of Rain Water Harvested from Roofing Sheets in Abuja Metropolis, F.C.T. in Nigeria. International Journal of Modern Analytical and Separation Sciences, 2(2): 91-102.

[8] Pejman, A. H., Nabi Bidhendi, G. R., Karbassi, A. R., Mehrdadi, N and Bidhendi, E. (2009): Evaluation of Spatial and Seasonal Variations in Surface Water Quality using Multivariate Statistical Techniques. International Journal of Environmental Science and Technology, 6 (3): 467 - 476.

[9] SrinivasamoorthyK., ChidambaramS., SarmaV.S., VasanthavigarM., VijayaraghavanK., R. Rajivgandhi, P. Anandhan and R. Manivannan (2009): 'Hydro geochemical Characterization of Groundwater in Salem District of Tamilnadu, India', Res. J. of Environ. and Earth Sci, 1(2): 22-33.

[10] C. Kreger (2004): "Water quality Assessment: Overview" Exploring the Environment Water Quality, Wheeling Jesuit University/NASA Classroom of the Future, pages 1-2.

[11] N. Rajkumar, T. Subramani and L. Elonga (2010): Groundwater water contamination due to municipal solid waste disposal-A GIS based study in Eroda city. Int. J. of Environ Sci. 1(1): 39-55.

[12] A. Nur. J.M. Ishaku and J.A. Bulus (2011): Application of chemometric Techniques in Groundwater quality Investigation in Angwere Area Jos North-central Nigeria. International journal of earth sciences and Engineering. 4(6): 965-972.

[13] APHA ( 2005): Standard Methods for the Examination of Water and Waste Water, twenty first ed. American Public Health Association, Washington, DC.

[14] WHO, Guidelines for Drinking Water Quality. 3rd Edn.Vol. 1 Recommendation, Geneva, 2004, 515.

[15] World Health Organization (2006): WHO Guidelines for the Safe Use of Wastewater, Excreta and Greywater: Volume II wastewater use in Agriculture. Geneva, Switzerland: WHO.

[16] E.O. Igbinosa and A.I. Okoh (2009): Impact of discharge wastewater effluents on the physic-chemical qualities of a receiving watershed in a typical rural community, Inter. J. of Environ. Sci. and Technol, 6 (2): $1735-1742$.

[17] Poulsen, H.D. (1998): Zinc and copper as feed additives, growth factors or unwanted environmental factors. J Anim Feed Sci, 7: 135-142. 
[18] Tong, S.; Von Schirnding, Y. E.; Prapamontol, T (2000): Environmental lead exposure: A public health problem of global dimensions. Bull. WHO 78: 1068-1077.

[19] Raphael Odoh, Odiba John Oko , Sunday Adebayo Kolawole , Ogbaji Eka Oche (2013): A Comparative Study of the Heavy Metal Content of Drinking Water in Different Storage Vessels. International Journal of Modern Chemistry, 5(3): 166-180.

[20] Okonkwo, O. J.; Maribe, F (2004): Assessment of lead exposure in Thohoyandou, South Africa. The Environmentalist, 24: 171-178.

[21] Malviya, R.; Wagela, D. K. (2001): Studies on lead concentration in ambient air PM10 and PM2.5 and characterization of PM10 in the city of Kampur. India. Atoms. Environ, 39: 6015-6026.

[22] MAHAFFEY, K. R., P. E. CORNELIUSSEN, C. F. JELINEK AND J. A. FIORINO (1975): Heavy metal exposure from foods. Environ. Health Perspect. 12:63.

[23] Jarup, L.; Berglund, M.; Elinder, C. G.; Nordberg, C.; Vahter, M. (1998): Health effects of cadmium exposure-a review of the literature and a risk estimate. Scand J. Work Environ. Health, 24: 1-51.

[24] E. Al Sabahi, S. Abdul Rahim, W.Y. Wan Zuhairi, F. Al Nozaily, and F., Alshaebi (2009): 'The Characteristics of Leachate and Groundwater Pollution at Municipal Solid Waste Landfill of Ibb City, Yemen', Amer. J. of Environ. Sci, 5 (3): 256-266.

[25] Alvarado, J. and A.R. Cristiano,( 1993): Determination of cadmium, cobalt, iron, nickel and lead in Venezuelan cigarettes by elecrothermal atomic absorption spectrometry. J. Anal. Atomic Spectrometry, 8: 253-259.

[26] Grandjean, P., (1992): Health significance of metals nickel exposure and its effects. J. Bio. Metals, 18: 7 13.

[27] Fox, M. R. S. (1976): Cadmium metabolism-a review of aspects pertinent to evaluating dietary cadmium intake by man. In: Trace Elements in Human Health and Disease, edited by A. S. Prasad. New York: Academic Press, Inc., vol. II, p. 401.

[28] A. F. Mohamed, W.Z.W. Yaacob, M.R. Taha, and A.R. Samsudin (2009): 'Groundwater and Soil Vulnerability in the Langat Basin Malaysia'. Euro. J. of Sci. Res, 27(4):628-635

[29] O.O Olanrewaju, and O.A. Ilemobade( 2009): Waste to Wealth; A case study of the Ondo State Integrated Waste Recycling and Treatment Project, Nigeria. Euro. J. of Social Sci, 8(1): 7 - 14.

[30] R. Shyamala, M. Shanti, and P. Lalitha (2008): Physicochemical Analysis of Borewell Water Samples of Telungupalayam Area in Coimbatore District, Tamilnadu, India, E-J. of Chem, 5 (4): 924-929.

[31] M.O. Jaji, O. Bamgbose, O. O. Odukoya, and T.A. Arowolo (2007): Water quality assessment of Ogun River, south west Nigeria. Environ. Monit., 133, 473-482

Citation: O. Raphael et.al, "Assessment of Some Anionic Parameters and Organic Components, as Pollution Indicators in Drinking Water Sources in Rural Areas of Abuja "F.C.T", Nigeria", International Journal of Advanced Research in Chemical Science (IJARCS), vol. 4, no. 8, pp. 22-30, 2017. http://dx.doi.org/10.20431/ 2349-0403.0408004

Copyright: (C) 2017 Authors. This is an open-access article distributed under the terms of the Creative Commons Attribution License, which permits unrestricted use, distribution, and reproduction in any medium, provided the original author and source are credited. 